\title{
The dual essence of pleasure: Willing, imagining and planning the Saussurean sublime and beautiful in surviving daunting nature and culture
}

\author{
Jui-Pi Chien \\ Institute of Foreign Languages and Literatures \\ National Taiwan University \\ No. 1, Sec. 4, Roosevelt Rd. \\ Taipei 10617, Taiwan \\ e-mail:jpchien@ntu.edu.tw
}

\begin{abstract}
This study seeks to update and expand the models of mind and consciousness that Ferdinand de Saussure conceived for the appreciation of linguistic signs. As a response to his theorization of the dual essence of language (a mixture of sounds and concepts), this study proposes a theorization of pleasure and understanding (a blending of different perspectives) deriving from our engagement with daunting situations in nature and culture. To begin with, the author discusses current neuroimaging findings that reveal how we may gain from low-arousal emotions. Certain benefits have been recognized that increase the pleasure and delight we may obtain through conscientious mental work rather than via instincts and preferences. Thus, in this context, the Saussurean network of differences is seen to be capable of generating motivated neural links that function to adjust our viewpoints. Further, in light of Adolphe Pictet's mingling of philosophical aesthetics and linguistics, this study corrects a misapplication of another Saussurean model (a conjunction of our perceptions of time and space, synchrony and diachrony) in appreciating the Kantian notions of imagination and the sublime. Instead of judging this model as a revelation of one single ideal viewpoint, Pictet's approach invites us to appreciate it as the functioning of a rigorous yet practical mind that is capable of devising multiple and useful perspectives. Notions of the sublime, the ugly and the beautiful are therefore equated as legitimate viewpoints that we should draw on so as to survive dealing with daunting situations in nature and culture. Finally, this study unifies and fortifies the Saussurean models through aligning them with a phenomenological approach to our memories, sensations and perceptions. Such integration empowers our imagination and confidence while we are widening our horizons to invent larger contexts for our objects of inquiry. All in all, the author cherishes the Saussurean models as a
\end{abstract}


combination of the linguistic, the aesthetic and the moral laws that altogether sharpen our way of devising rationales that may boost the wellbeing of the community.

Keywords: mind and consciousness; low-arousal emotions; pleasure and delight; the sublime and beautiful; perspectives and adjustment; memories, sensations and perceptions

\section{The Saussurean sign system considered as a neuro-evolutionary framework in relation to current neuroscience ${ }^{1}$}

Is it actually possible to gain something from emotions such as fear, sadness or repugnance while engaging with the arts? Neuroscientists working on bridging the gap between our responses to objects in everyday situations and our perceptions of the arts have questioned the usefulness of setting up binary oppositions for our inquiry of emotions (Vartanian 2009; Brown, Dissanayake 2009; Eskine et al. 2012; Baas et al. 2012). The approach of measuring emotions in terms of valences suggests that we are not very likely to benefit from the states of feeling uncertain and disconcerted. Presumably, high-arousal emotions such as anger and joy would induce us to take action: either to save ourselves from immediate danger or, say, to gain satisfaction from gazing at attractive faces or pleasant landscapes, respectively (Ishai 2012). Measured within this line of thinking and observing, our preference for beautiful objects explains why we gain pleasure, harmony and meaning, whereas our aversion to horrifying things is rather dismissed in achieving similar benefits. In addition, the role of our emotions in shaping our behaviour is thought to have largely derived from our drives, instincts or physical arousal (Thornhill 2003; Eskine et al. 2012).

Recent neuroimaging findings reveal that presumably low-arousal or negative emotions can actually empower us in several different ways: (1) we become active, organized and focused in terms of thinking and paying attention (Baas et al. 2012); (2) we turn out to be resourceful and intelligent in situations that demand our favours to transform someone else's misery and distress into joy and happiness, peace and harmony. It is discovered that mothers are quite capable of devising strategies in dealing with their, and other, babies' ambiguous facial expressions (Lenzi et al. 2009); (3) we may acquire heightened appreciation of abstract art and emotional attachment to art forms that at first appeared unknown or unfamiliar (Eskine et al. 2012; Vessel et al. 2013; Starr 2013). These findings invite us to devise a model of interpreting the arts that, on the one hand, will serve to revise the essentialist view of emotions, and on

1 This section is a slightly modified part of an already published article (cf. Chien 2017). 
the other hand, will induce enlightening interpretations by way of observing dynamic interactions between our emotions and our ways of evaluating sensory input.

Since in the arts we frequently experience emotions usually labelled as low, weak or negative, we should reconsider certain key concepts utilized in evolutionary psychology and neuroaesthetics that used to enhance the benefits of strong emotions we may experience in nature and culture. We should also seek to develop a suitable neuro-evolutionary framework that would serve our purpose of conceiving a dynamic model of observing emotions and evaluations for our appreciation of the arts. To begin with, in any situation of perceiving the arts, some kind of safety distance is already ensured: we have no reason to escape from or be overwhelmed by the real thing unless we have intentionally stepped into certain types of art. What really makes us feel uncomfortable, uncertain and even alarmed has something to do with making sense of what we are experiencing.

Unlike situations in nature, in which we have to make our decisions immediately to flee or to fight, to survive or to perish - in culture we have ample time to sort out how we are coping with any ghastly images. This implies that we have to make efforts to process information so that we can regain the kind of peace and harmony that would please us in a different way. The kind of pleasure, satisfaction and reward we gain from processing the so-called low- or negative-valence emotions is not so direct and transparent as that received from high- or positive-valence ones on first encountering something. The reward is the result of detail-oriented, categorical and systematic analyses that involve high-order cognitive and motor areas in our brain (Lenzi et al. 2009; Baas et al. 2012: 1005-1006). Such analyses may enable us to detect meaningful patterns or to become outspoken in justifying certain values we adhere to (Baas et al. 2012: 1012).

In the sphere of culture, emotional discomfort may induce us to create ties with what we are engaging with (Greenspan 1988: 75). Similarly to mothers who would react to their own, as well as someone else's, infants, we may become more or less liaised with sorrow- or horror-inducing images due to our incessant imagining of the strategies we are adopting. This said, the notions of adaptation and success defined in evolutionary psychology should also be more or less revised: while perceiving the arts in culture, we choose to adapt to, or to live with, horror and sorrow by stepping back and contemplating potential moves. The safe distance, created either physically or mentally, does not merely enable us to keep our integrity: it allows for the emerging of intriguing ideas or devising of strategies so that we would be able to unite with disconcerting others creatively.

When taking our success at dealing with fear, horror and sorrow as the guiding principle that serves to bridge the gap between nature and culture, and the one between everyday situations and art appreciation, we should also consider how 
evolutionary biology could boost the emergence of our model. According to the notion of biophilia, our preference for joy-inducing environments has become part of our genetic constitution to the extent that we are able not only to ward off danger, but also to increase the leisure needed to create arts (Ulrich 1993). However, the binary opposition created between biophilic and biophobic impulses ignores our potential of dealing with negative aesthetic judgments. As discussed previously, certain adaptive benefits may still rise from our integration of unpleasant feelings and impressions (Kellert 1997: 147-161).

The hypothesis of a mirror system has been put forward in order to explain how our evolutionary, developmental, and experiential processes function together within a certain time span of observing, imagining and emulating (Kaag 2009). The mirror neurons, which were first found in macaque monkeys' brain area for hand control, may play a significant role in governing the coordination between our sensing and knowing, hearing and speaking, watching and performing tasks (Donald 2001; Arbib 2012). The system as a whole may facilitate our foreseeing of possibilities or potential developments before we decide to take action. At the starting point of observing any kind of situation in nature and culture, patterns of our neural circuits of perceiving and imagining are not very different; rather, they are almost blended and they collaborate to create perspectives for further applications (O'Connor, Aardema 2005; Gallagher 2006; Kaag 2009; Lenzi et al. 2009). After taking action to explore a situation, we become more or less removed from our initial position. Our mind and behaviour are reshaped or restructured by details found in this situation: both engaging intricacies and foreboding signs may trigger a remapping of neural patterns in our brain (Kaag 2009).

The mirror system explains our biological aptitude of toying and teaming up with fear, horror, or any eerily strange situations in nature and culture. We cannot ignore the fact that ambiguities or foreboding signs - particularly when detected via seeing and hearing - actually instigate a rigorous play drive, cognitive or high-level processing in our brain (Panksepp 1998: 289-290, 2012; Lenzi et al. 2009). Instead of simply inhibiting feelings of fear and anxiety, our secondary and tertiary cortices always devise changing and intriguing strategies so that we can cope with uncertainties and unpredictability (Donald 2001). Both nature and culture can be seen in this light as part of our inner biological conditioning that keeps evolving to achieve greater success and higher adaptability in diverse situations. However, the mirror system does not appear to be careful or precise in terms of judging and choosing, so that in certain cases it may simply react without enabling us to think twice. It becomes equally charged whether we simply imagine doing something, watch others carrying it out, or perform it on our own (Gallagher 2006; Kaag 2009). Given such an obscure relationship between our actions and intentions, we would need to consider some 
lapses of trials and errors, certain forms of pretending and deceiving, if we count on this system as the sole basis of justifying our behaviour.

Recently, neuroscientists have come up with a rather comprehensive system - the default mode network - and visualized its functional connections with the mirror system (Fig. 1). It was discovered that such a network functions to coordinate between various specialized subsystems in our brain (Molnar-Szakacs, Uddin 2013). The network is always active, except that it reveals reduced links or structured ideations when we are working out certain tasks such as appreciating strange or unfamiliar artworks (Vessel et al. 2013). It has also been discovered that part of our prefrontal cortex is equipped with a node that is involved in self-related processing, while part of our posterior cortex participates in other-related processing (Molnar-Szakacs, Uddin 2013: 8). From these discoveries we can gather some sophisticated ideas for the shaping of our model: we are indeed quite selective, motivated and spontaneous when engaging with others in nature and culture, yet our actions already reveal how we have absorbed others' features and evaluated various perspectives. On the one hand, such a dynamic interaction, or, rather, "privileged access" structured between the mirror system and the default mode network (Vessel et al. 2013; Molnar-Szakacs, Uddin 2013), serves to modify the automatic responses generated by the mirror system; on the other hand, it strives for the kind of conscientious, intelligent and meaningful collaboration - that between oneself and alarming situations, and that between our emotions and evaluations of situations - much needed in our model.

General difference of meanings (only exists in relation to forms)

General difference of forms

(only exists in relation to meanings)

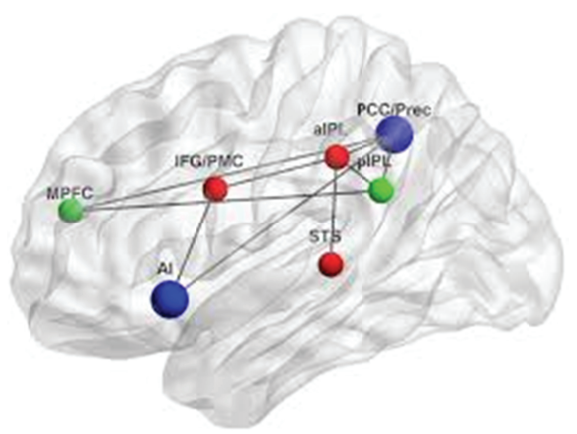

Figure 1. Convergence between F. de Saussure's sign system (left) and the default mode network cum mirror system (right) (Saussure 2006: 24; Molnar-Szakacs, Uddin 2013: 7).

Neurobiological discoveries enable us to recognize our own invention of links and approaches as the main task in our appreciation of the arts in the wake of neuroaesthetics. Similarly to how the default mode network wilfully coordinates between our emotions and evaluations, also the Saussurean sign system conceived 
as a network of differences achieves the following: both models are characterized by the trait of constant yet moderate adjustments while we are seeking meaning and understanding (Fig. 1). These self-willed revisions driven by low-arousal emotions are not so overwhelming as to lead to a complete change of the system. Rather, they enable us to deviate slightly from our beliefs - achieving some kind of relative yet creative infidelity to the past - so that we can cope with complicated situations (such as coining verb conjugations) at present (Saussure 1993: 97a-98a, 108a). This trait actually increases our chances of making intelligent moves, devising strategies or searching for means that empower our staging of self-relevant, intriguing and future-oriented interpretations. It is therefore argued that the Saussurean sign system provides us with a proper neuro-evolutionary framework in mapping out our meaningful collaboration with diverse beings under all circumstances.

\section{The Saussurean sublime and beautiful conceived as a convergence of the linguistic, the aesthetic and the moral laws}

\subsection{Phenomenology and moral psychology in relation to current neuroscience}

As opposed to neuroaesthetics and certain strands of evolutionary psychology and biology, which attribute the true cause of our survival to strong emotions, instincts and physical arousal, the neuro-evolutionary sign system is based on our capacity of intuiting and recalling memories of past experiences. Such an approach emphasizes our motivation and virtuosity of revising hypotheses, beliefs and perceptions while coping with low-arousal emotions. It observes (1) how we select and string together multiple incidents we have experienced in the past in devising our hypotheses of acting and behaving for the present; and (2) whether we are able to moderate our emotional discomfort in light of new perceptions we gather from our dealings with clues and evidence (Bergson 2004[1912]; Greenspan 1988: 83-107).

Seen through the neuro-evolutionary framework, our survival in nature and culture is governed by our skills of unifying diverse values, recognitions and rewards gathered at different stages of our inquiry. Such practical adaptiveness measured in semiotic terms is indeed a matter that resists generalization of responses to eerie and alarming situations. Recent experiments surrounding the functioning of the default mode network reveal that our attitudes actually vary widely even though we are dealing with the same task: we may feel touched or disgusted by oddities; we may choose to enter or to walk away from them (Starr 2013: 27, 49-51; Vessel et al. 2013). Our choice and survival is actually governed by our willingness to recognize 
something attractive in our memories or lived experiences (Ricœur 2005: 125-126; Bergson 2004[1912]). Our memories may provide us with some stimulating clues and evidence that serve to boost our survival here and now.

The neuro-evolutionary framework enables us to cope with the fact that we are all widely divergent as regards our tastes and choices. To render the Saussurean network of differences even more suitable for our observation and application, we now elucidate the strengths of Saussure's approach through aligning it with certain Kantian notions (the moral sublime and the categorical imperative) and the phenomenological way of thinking. The goal is to unify their ideas so as to form a proposition or a hypothesis that serves to engage with the key problem we have here and now: how we may invent our own approach to daunting situations in nature and culture through observing subtle connections between our language, perception and emotion. The neuro-evolutionary framework is thus seen as a convergence of the linguistic, the aesthetic and the moral laws. Not only does it overcome the problem of binary oppositions found in neuroaesthetics, but it also promotes a non-reductive idea of rational, imaginative and yet sympathetic agency much needed in scientific arts and humanities today. ${ }^{2}$

\subsection{Links between Kant and Saussure: Paul de Man revised in light of Adolphe Pictet}

Focusing on the model showing a concurrence of two axes, the syntagmatic and the associative (paradigmatic) as well as the synchronic and the diachronic (Fig. 2), we can draw on a couple of elaborations that serve to relate the Saussurean model to strands of aesthetics and phenomenology. To begin with, the junction of the two axes is seen as "a single and particular point of view, a privileged place" through which and from which we would gather the most pleasant view and sufficient understanding

2 According to one of the anonymous reviewers, Saussure appears to have addressed some kind of collective mind in the third course of lectures (Saussure 1993), and we are advised to make distinctions between the individual and the collective minds while examining Saussure's three courses. However, the author would argue that such distinctions are temporary, or rather, non-existent in the kind of network that Saussure illustrated in his own writings (Saussure 2006). His own writings enlarge on our mental capacity of integrating or playing on differences of forms and meanings. This is why the author finds Saussure inspiring when relating his system of signs to neuroaesthetics and moral psychology. The Saussurean system serves to overcome the old problem of binary oppositions - that between strong and weak emotions and that between public and private; good and bad tastes - found in both fields. Seen through the Saussurean network, our mind is both individual and communal. Although we may have acquired certain communal laws (such as grammatical rules and tastes), from time to time we make our own choices or come up with our own satisfying solutions to problems. 
of sentences, texts and buildings (de Man 1996[1984]: 77-78). It is this viewpoint that controls our imagination working in such various ways as apprehension and comprehension: the former moves across space, the latter through time. While engaging with the usefulness of the linguistic model, Paul de Man surmised that we are not very likely to make sense out of something that goes beyond the limit of our horizons. He thus advised that we should always be alerted to the suitability of texts we are devising in terms of reading, writing and appreciating.

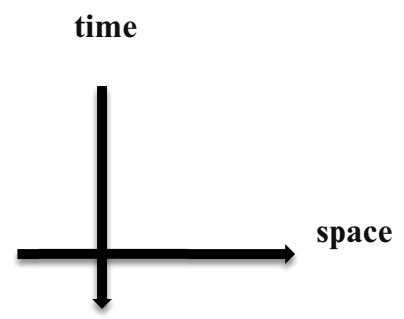

Figure 2. The conjunction of time and space in Saussure (mapped by the author).

Our imagination so conceived is like an economy that constantly regulates our losses on one axis and gains on the other, and vice versa. This ensures that we always create and gather meaningful entities rather than pointless fragments. Although Paul de Man appears fairly justified in drawing on the Saussurean model (enhancing the linguistic principle as a powerful means) to revise the Kantian notions of imagination and the mathematical sublime, his remarks, seen today, do not supply the only valid condition of theorizing the Saussurean sublime and beautiful. We should think about two aspects that de Man may have ignored: (1) there should be some heuristic value implied in Kant's original idea that our imagination or horizons may extend endlessly beyond the control of our reason and the confinement of the earth (Kant 2000: 139$140)$; (2) we may actually gain something even while creating or encountering things that appear like complete nonsense.

According to Saussure, the junction of the two axes reveals a sort of grammar, i.e. the principle of analogy, through which we devise the different cases and tenses of a verb through associating them with other verb changes of the same category. However, due to our memories or perceptions, we can also coin ungrammatical or monstrous forms through applying exactly the same principle (Saussure 2006: 104109). The principle of analogy appears as the key to adopting the non-judgmental and non-teleological attitude that characterizes the neuro-evolutionary sign system: it allows for the coexistence of the sensible and the absurd; the beautiful and the ugly; the merits and the shortcomings. Such an integration of diverse judgments within 
the same system also finds its nourishing context in the tradition of philosophical aesthetics.

The way in which Saussure argued for the peculiar logic of the sign system appears compatible with that of his teacher Adolphe Pictet. In light of Pictet, notions of the sublime, the ridiculous and the ugly can be bridged with that of the beautiful. Pictet considered these seemingly diverse judgments all to be deriving from the same ground in our mind and found that we cannot dispense with these diverse viewpoints in appreciating nature and the arts ("le beau et le sublime [sont] dérivés d'une source commune"; "[les] voies diverses se complét[ent] l'un par lautre"; Pictet 1875[1856]: 184-185). What he proposed about the common ground appears very much like the structure of a sign, made up by the form and the idea; the image and the concept; the signifier and the signified. Within the mental structure of the beautiful, the gap between image and concept disappears, and we immediately acquire sweet and joyful sensations; within those of the other notions, the gap (séparation; incommensurabilité; disconvenance; désaccord) is made so prominent that we feel alarmed (it alerts us), but we can still manage to transform our fear and horror into some pleasure and delight (Pictet 1875[1856]: 169-171, 208-209).

Considered as symbiotic qualities of our mind and intelligence, viewpoints such as the sublime, the ridiculous and the ugly collaborate within a network of differences. Although the disagreeable notions among them may evoke certain instinctual and neurotic qualities of our mind, we would know how to mingle them well with agreeable thoughts just for our mental wellbeing (Pictet 1875[1856]: 184-185, 212). Moreover, Pictet made the point that we need these viewpoints to widen our horizons so that we could gain the strength to make things take a favourable turn for us (le triomphe). Compared with the idea of the beautiful, which involves some cultural differences, the notion of the sublime is thought to be fairly cosmopolitan. The sublime appears far-reaching in the way that it enables us to cope with something vitally shared between humans: it is about gaining ideas (pour nous élever à l'idée) to survive unpleasant encounters in nature and culture (Pictet 1875[1856]: 183).

Pictet (1875[1856]: 184) in particular drew on the Kantian notion of moral sublime to argue that the sublime as well as the beautiful should find their most compelling and effective context within a society or a community. The sublime is compulsory and imperative not just because certain traits we spot on objects instigate our drives and instincts, but also because certain communal laws (in our memory) constantly speak to us, as if they were the authorities commanding us to take certain paths in surviving daunting situations (Pictet 1875[1856]: 184). Pictet's engagement with the Kantian notion provides us with a clue to unifying aesthetics and linguistics in Saussure: we should consider expositions gathered on both sides (deux côtés) - a perceiving subject and his or her perceived objects; the thinking and enacting subject 
and his or her environments - so as to appreciate the sublime and the beautiful as heuristic tools that serve to organize our expanding and changing horizons (Pictet 1875[1856]: 182-183). Instead of judging the Saussurean model (Fig. 2) as a revelation of one single ideal viewpoint, Pictet's study invites us to appreciate the model as the functioning of a rigorous yet practical mind that is capable of devising multiple and useful perspectives. ${ }^{3}$

\subsection{Explorations guided by the moral feeling and the categorical imperative ('as-if' analogical reasoning shared by Kant and Saussure)}

The conjunction of the two axes actually implies some sort of the moral sublime in Kant and Saussure. The sense of morals implied in the sign system is very much about our conscience that is made spontaneous due to our absorption and application of communal laws. Any junction formed in the changing sign system is valued as a legitimate choice - a thoughtful and sympathetic viewpoint - that unites our demands and interests with our observations of things, humans and environments. The system motivates itself, and is thus self-standing, self-serving and self-governing. This explains why Kant drew on ideas of the law, a priori principle, and the communal or common sense in revising empirical techniques of inducing pleasure and delight as devised by Edmund Burke (Kant 2000: 158-159; 173-176). In Kantian terms, self-motivation claims the a priori principle to justify the fact that we are all widely divergent with our tastes and judgments. We should rather observe how we have made our own efforts in reaching out to others within the community.

3 When drawing on the link between Saussure and Pictet in revising de Man, the author means to be analytical rather than biographical and chronological, focusing on mapping ideas concerning the unification of aesthetics and linguistics shared between the master and the disciple irrespective of Saussure's criticism and modification of Pictet's approach to languages. Saussure actually came up with three review articles for the publication of the second edition of On the Origin of Indo-Europeans or the Primitive Aryans: An Essay on Paleontological Linguistics (1878) (Joseph 2012: 219-220). This study draws on useful information found in the first article, in which Saussure spotted and showed admiration for a certain continuity between Pictet's earlier and later projects. He thought Pictet's study of ancient languages is actually grounded upon Pictet's profound studies of literature and philosophical aesthetics (including both Kant and Hegel) as revealed in On the Beautiful in Nature, Art and Poetry (1875): "ses recherches esthétiques et littéraires lui fournirent ainsi le fondement de son éducation linguistique; Si l'on y regarde de près, on reconnaîtra sans peine que toutes les æuvres de Pictet sont bien nées au foyer de la même pensée" (Saussure 1878). Seeing with hindsight, the author values Saussure's favourable comments as the clue to introduce the scope of conceiving the sublime and beautiful into his own work. Meanwhile, Pictet's contemplations on aesthetics can also find justifications through the Saussurean concept of sign entities. 
Specifically, the genuinely universal condition of attaining pleasure and delight boils down to our conscientious communication and collaboration with others in the community. We ought to go beyond our own horizons and seek to evaluate our own judgments from the point of view of other people. After repeating such an interchange of positions for a while - honouring it as a kind of training and learning that serves to sharpen our perceptions - we should be able to achieve spontaneously a certain degree of consistency in terms of thinking, imagining and reasoning (Kant 2000[1790]: 174$175 ; 180)$. Such consistency, or rather, our strength of unifying diverse opinions and evaluations (as shown in Fig. 2), elaborates on the legitimate condition of attaining the moral sublime in Kant and Saussure. Our persistence and consistence in engaging with imagining and reasoning in a broad-minded way may actually enable us to overcome binary oppositions - certain biased impressions against the ugly and the ridiculous in particular - that typically characterize the judgmental and narrowminded way of thinking (Kant 2000[1790]: 180-182).

There are indeed some merits in widening our horizons, yet, according to Kant and Saussure, the type of pleasure and delight we gain from such broadening is fairly intellectual. It is about applying our intelligence to devise perspectives - some kind of meta-viewpoints - so as to really integrate a sufficient number of diversities and differences. Our mind can indeed travel across space and time as freely and as far away as possible, while our sense of vocation and mindfulness summons us to revisit our point of departure from time to time. This point (a principle or a maxim), said to unify our perceptions of space and time, can actually be corrected: it contains not only a privileged position that supervises a proper understanding, but also multiple conscientious choices that generate innovative approaches to problems time after time. Our respect for the communal law - also conceived as a kind of duty and moral feeling in Kant - actually guides our selection of principles or maxims in expanding, modifying and inventing our horizons.

Apart from developing strategies of coping with abrupt sensations of fear and horror, we should also consider vigorous intellectual exploration guided by moral feelings (such as love and sympathy) as a way of experiencing intense pleasure and delight (Kant 2000[1790]: 177, 179-180; 2012[1785]: 15-16, 69). Moral feelings command our enthusiasm and determination in engaging in an arduous process of reasoning and imagining. Provided that such emotion is constrained by the communal law, we are obliged to honour the approach that we deliberately adopted at the beginning of our inquiry. It seems we are so engrossed and we are already quite well adjusted that we do not suspect the strictly defined course of reasoning delineated by the approach (Kant 2012 [1785]: 33-34, 68-69). However, according to Kant, such imperative as enforcing the conformity between maxim and action should be accompanied by the self-governing law of willing and promoting the universal 
validity of our own choices and actions (Kant 2012[1785]: 34). This suggests that we have the freedom and flexibility to change our approach - experimenting with our ideas while engaging in a broad-minded way of thinking - so that we may prompt much anticipated responses, such as pleasure, delight and understanding, to our own work.

The Kantian notion of categorical imperative broadens our imagination and motivation of inventing our positions, attitudes and approaches of coping with daunting tasks or situations (Velleman 2006). Although this notion has been criticized in philosophical discourses as empty formalism, implying that enactive subjects simply replicate their beliefs (already formed in the past) without making efforts to devise new perspectives, more recent studies actually encourage us to appreciate such a notion as a "leap of faith", through which we revise or bypass any obsessive or judgmental attitudes while considering approaches we are about to adopt (Velleman 2006: 311). Such a revision or detour is thought to increase not only the flexibility of our behaviour, but also our chance of surviving daunting situations (Holton 2011). Within the neuro-evolutionary and non-judgmental sign system, we behave for reasons that we can intuit and imagine, rather than those we firmly believe in.

Our strength of imagining and devising useful rationales serves to unify the aesthetic, the moral and the linguistic laws on our path towards achieving the Saussurean sublime and beautiful. Seen through Kant and Saussure, the consolidated neuro-evolutionary framework functions not only to acquire knowledge, but also to deal with nonsensical, monstrous phenomena or biased impressions. Kant and Saussure converge on the 'as-if' analogical way of reasoning and imagining: the philosopher drew on such logic to argue for the practicality of the categorical imperative which forces our mind to associate something puzzling spotted at present with what we already knew or experienced, while the linguist applied the same principle to conceive the dynamics between our past and present as a symbiotic development. Our perception formed at present is therefore subject to constant revisions: our memories of past experiences may either facilitate or complicate our making sense of current situations. Additionally, there is a good chance of surviving alarming or ambiguous states we are encountering here and now. We are obliged to make good use of our memories so that we may gather clues to render seeming nonsense more or less sensible to the community and ourselves. 


\section{Willing, imagining and planning the Saussurean sublime and beautiful}

\subsection{Symbiosis of memory-images, our sensations and perceptions - Paul de Man further revised}

Rather than making qualitative distinctions between our emotions, we now equate them on the same level so as to promote the discovery of useful rationales. Such a change of attitude enables us to rely on our intuitions and sensations as guides in proposing inventive approaches. Actually, this re-appraisal of our emotions also serves to modify our perception of unfamiliar occurrences in nature and culture. We are reliving and re-contextualizing with our body and mind any emotion that may occur while we are dealing with strange happenings. We are also revealing the fact that our ability of feeling and intuiting can be as powerful and effective as enacting and performing through our body. The so-called "analogous intuitions" formed as efficient connections between our current situations and lived experiences - while we are recalling memories that appear stunningly similar to current situations - also govern how we take steps to benefit from our dealings (Bergson 2004[1912]: 70-71). In our new task, there is a slight chance of feeling overwhelmed or defeated since we are empowering ourselves from inside our mind and consciousness; we are measuring the survival of our memories, intuitions, feelings and sensations in light of how we are using them (Bergson 2004[1912]: 232; Ricœur 2005: 124-125). We will draw on well-selected memories, play on attractive correlations between these memories and sensory information, and hopefully we will improve our ease and fluency of processing strange and deviant forms (Reber 2012).

Appreciated in the context of phenomenology, our emotions and sensations are just like various attitudes and behaviours that constitute our intriguing perceptions (Merleau-Ponty 1964). Specifically, we gain from the kind of "memory-images" that our sensations have nurtured and that rigorously work out to shape and to modify our perceptions (Bergson 2004[1912]: 170). Such images are quite different from pure memories: they are able to reach out and they constantly trigger subtle movements in our body and mind - enabling us to sharpen our perceptions - rather than simply recognize specific times, places and objects (Bergson 2004[1912]: 178). Memoryimages function to enrich our capacity of integrating sensations, memories and perceptions while we are managing daunting tasks: they render our mental acts of recalling, searching and understanding equally engaging in our new task. In addition to factual details that we may gather from the past, we mainly draw on our mental acts of expanding and conjuring that memory-images are likely to create. While actively working out our complicated tasks, we are trying out many possible ways of seeing considering as many different ways of positioning ourselves - with an eye to devising rationales that operate to unify clusters of sensory forms we are engaging with. 
General difference of meanings

(only exists in relation to forms)

General difference of forms

(only exists in relation to

meanings)

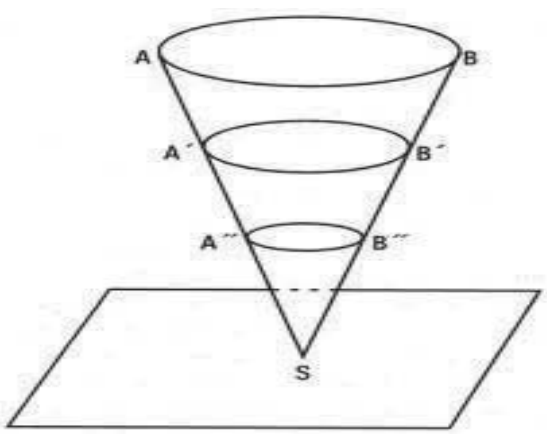

Figure 3: Saussurean and Bergsonian models bridged on the same horizon (Saussure: 2006: 24; Bergson 2004[1912]: 211).

Let us shed light on the two Saussurean models of our mind and consciousness (a network of differences; a conjunction of time and space) through the evolving cone of memory (also conceived as a sensorimotor system) by Henri Bergson (Fig. 3). Just imagine that we are exploring any daunting situation in nature and culture, and that we have the privilege of coming up with at least three perspectives to unify our memories and observations, sensations and perceptions, within three varying yet adjacent environments (Bergson 2004[1912]: 128). Breaking down and working out our situation in this fashion, we cannot foresee what we are achieving ultimately unless we have exhausted trying out all potential perspectives. While thinking and moving from the spaces nearest to us to the areas further away, we gradually gather some ideas about our situation through revising our perspectives. The way we estimate things around us at the beginning of our journey cannot be very sophisticated: it may be just our immediate reaction to or a close study of sensory forms confined within a limited area (Bergson 2004[1912]: 185-186). However, as we travel further to the more remote and magnificent areas, we are likely to see things behind the surfaces our memory-images are exerting their power of penetrating concrete forms, blurring the boundaries between them and aligning our sensory impressions - so much so that we gain the intelligence of revising typical ways of judging and interpreting our situation.

The phenomenological approach to attaining the Saussurean sublime and beautiful is definitely non-teleological and eye-opening. Rather than priding ourselves on being able to see through everything right from the start, we actually manage to widen our horizons by way of exploring and working out our situation step by step. Such a humble and conscientious approach enables us to consolidate our intriguing discoveries through bridging (merging and trimming) several changing perspectives. While seeing and moving around within a small space, we are quite likely to be cued instinctively to pay more attention to certain parts of it rather than others, to gaze at 
eye-catching details but shy away from unpleasant-looking forms. In this instance, we do not seem to gain much support from our memories (or memory-images) in overcoming some such biased or unbalanced views of our situation. However, as we keep on expanding our circles of exploration, we are gathering more lived experiences from our journey, and in the meantime, we are recollecting an ever-growing number of memories in our mind (just like those widening slices marked on Bergson's cone). Such an approach allows us to gain a better chance of drawing on really useful memories to empower our observations (mental acts) throughout our journey. These self-willed and well-selected memories - irrespective of their actual settings in times and spaces - are ready to work wonders for us, guiding us to come up with all-embracing perspectives from deep inside our mind and consciousness (Bergson 2004[1912]: 188-189, 211-212, 217-219).

\subsection{Looking forward to our conscientious yet rewarding journeys}

The sensorimotor sign system promotes our wellbeing by adopting a balanced approach to surviving daunting situations in nature and culture. It encourages us to invent a process of willing, choosing and multiplying meaningful connections between our recollections, sensations and observations. Following such a process, we are likely to devise rationales that appear as well built and organized as pyramids (Bergson 2004[1912]: 226-227). Thus, through the notion of moral sublime, we can summarize the merits of bridging Kant and Saussure as follows: (1) we should definitely crave for a flexibility of our positions and behaviours even when coping with fear and uncertainty; (2) we constantly open and reopen our horizons to such an extent that we become resourceful in brightening our weird situations; (3) we gain not only pleasure and delight from the rationales we are inventing and presenting to the community, but also discernment and recognition of certain values that we cherish and that may also win the approval of the community (Merleau-Ponty 1989[1962]: 22; Ricœur 2005: 123-124).

By way of breaking down any situation into segments (as if it were a sentence or a painting) and gradually widening our circles of exploration, we can actually gather various contexts and perspectives to shed light on both unsettling and captivating details that impressed us at the beginning of our journey. We indeed need to carry with us "just enough" memory-images of such originating details ("juste assez de l'image"; Bergson 2004[1912]: 212) to survive uncertainty and unpredictability in nature and culture (Ricœur 2005: 125; 139). Our persistence of re-entering and revisiting our initial points of contact enables us to strengthen the arguments that we are presenting to the community. We may also imagine that we are equipping ourselves with three different personalities - a painter, an explorer (or a naturalist) 
and a linguist - when entering daunting situations in nature and culture (Humboldt 2010[1845-1862]). Although we have acquired our expertise in different fields, we mainly absorb from these personalities the mind and behaviour of configuring and reconfiguring our situation attentively and actively (Merleau-Ponty 1993: 59-75).

When acting like a painter, we constantly alternate between watching and actualizing our observations with means at hand. Something that may appear slightly disconcerting is whether we should render our sketches abstract and stylized (just for ourselves) or transcribe everything we have seen in impeccable detail (for the community). Adapting our mind and behaviour to that of an explorer or a naturalist, we become enthusiastic about planning and travelling with an eye to discovering any rare species or unbeaten paths. While taking in our situation that presumably is located in a foreign land, we have the duty of collecting exotic materials such as minerals and plants to be admired and evaluated by the community back home. In addition, considering that we already read and speak some of the local languages, we are licensed to deal with our situation as if we were linguists. We are eager to discover how people communicate with one another in various everyday scenarios and whether they are able to take our needs into consideration (providing us with some local hospitality or knowledge) during our stay. Although we may well stumble at certain points in expressing ourselves, all in all we leave the impression of mingling well with the locals and moving around with ease and confidence.

We are actually applying our imagination and intelligence to manage our daunting situations. Throughout our journey, we contemplate how we should maintain equilibrium between our own needs and those of the community, and that between our absorption of concrete and intricate details and our invention of an inclusive landscape that serves to please the community. It is our duty to reinvent the sort of nature and culture we are exploring with the skills and temperaments we have acquired in our home country (Humboldt 2010[1845-1862]: 72, 89-90). With the scheme of travelling between the home country and foreign lands, we are supposed to boost the wellbeing of the community as if we were creating impressive art or briefing some guidelines of appreciating foreign lands and tongues as compared and contrasted with our own. While interacting with daunting situations, we reflect on any subtle changes occurring between our mind and eyes, yet we seek to gain strength and ideas for our body and mind (Humboldt 2010[1845-1862]: 90-91; Merleau-Ponty 1993: 121-149). All in all, we make real efforts to entice the community into our method of devising perspectives, rationales and strategies. 


\section{References}

Arbib, Michael A. 2012. How the Brain Got Language: The Mirror System Hypothesis. Oxford: Oxford University Press.

Baas, Matthijs; Dreu, Carsten de; Nijstad, Bernard A. 2012. Emotions that associate with uncertainty lead to structured ideation. Emotion 12(5): 1004-1014.

Bergson, Henri. 2004[1912]. Matter and Memory. New York: Dover.

Brown, Steven; Dissanayake, Ellen 2009. The arts are more than aesthetics: Neuroaesthetics as narrow aesthetics. In: Skov, Martin; Vartanian, Oshin (eds.), Neuroaesthetics. Amityville: Baywood Publishing Company, 43-57.

Burke, Edmund 2008[1757]. A Philosophical Inquiry into the Origin of Our Ideas of the Sublime and Beautiful. Oxford: Oxford University Press.

Chien, Jui-Pi 2017. Spectatorship as a play on moral ambiguities: Neuro-evolutionary semiotic approach to lowly arousal emotions. Semiotica 215: 325-339.

Donald, Merlin 2001. A Mind So Rare: The Evolution of Human Consciousness. New York; London: Norton.

Eskine, Kendall J.; Kacinik, Natalie A.; Prinz, Jesse J. 2012. Stirring images: Fear, not happiness or arousal, makes art more sublime. Emotion 12(5): 1071-1074.

Gallagher, Shaun 2006. How the Body Shapes the Mind. New York: Oxford University Press.

Greenspan, Patricia 1988. Emotions and Reasons: An Inquiry into Emotional Justification. New York; London: Routledge.

Holton, Richard. 2011[2009]. Willing, Wanting, Waiting. New York: Oxford University Press.

Humboldt, Alexander von 2010[1845-1862]. Cosmos: Sketch of a Physical Description of the Universe. Vol. 2. Cambridge: Cambridge University Press.

Ishai, Alumit 2012. Art compositions elicit distributed activation in the human brain. In: Shimamura, Arthur P.; Palmer, Stephen E. (eds.), Aesthetic Science: Connecting Minds, Brains, and Experience. New York: Oxford University Press, 337-355.

Joseph, John E. 2012. Saussure. Oxford: Oxford University Press.

Kaag, John 2009. The neurological dynamics of the imagination. Phenomenology and Cognitive Sciences 8: 183-204.

Kant, Immanuel 2000[1790]. Critique of the Power of Judgment. (Guyer, Paul. ed., trans., Matthews, Eric. trans.) Cambridge: Cambridge University Press.

- 2012[1785]. Groundwork of the Metaphysics of Morals. [1st rev. edition] (Gregor, Mary, trans., ed.; Timmermann, Jens, ed.; Korsgaard, Christine M. intr.) Cambridge: Cambridge University Press.

Kellert, Stephen R. 1997. Kinship to Mastery: Biophilia in Human Evolution and Development. Washington; Covelo: Island Press; Shearwater Books.

Lenzi, Delia; Trentini, Claudia; Pantano, Patrizia; Macaluso, Eugenio; Iacoboni, Marco; Lenzi, G. L.; Ammaniti, Massimo 2009. Neural basis of maternal communication and emotional expression processing during infant preverbal stage. Cerebral Cortex 19: 1124-1133.

Man, Paul de 1996[1984]. Phenomenality and materiality in Kant. In: Warminski, Andrzej. (ed., intr.), Aesthetic Ideology. Minneapolis: University of Minnesota Press, 70-90.

Merleau-Ponty, Maurice 1964[1948]. The film and the new psychology. In: Sense and NonSense. Evanston: Northwestern University Press, 48-59. 
- 1989[1962]. Association and the projection of memories. In: Smith, Colin (trans.), Phenomenology of Perception. London: Routledge, 13-25.

- 1993. The Merleau-Ponty Aesthetics Reader: Philosophy and Painting. (Johnson, Galen A.; Smith, Michael B. eds.) Evanston: Northwestern University Press.

Molnar-Szakacs, Istvan; Uddin, Lucina Q. 2013. Self-processing and the default mode network: Interactions with the mirror neuron system. Frontiers in Neuroscience 7(Article 571): 1-11.

O'Connor, Kieron P.; Aardema, Frederick 2005. The imagination: Cognitive, pre-cognitive, and meta-cognitive aspects. Consciousness and Cognition 14(2): 233-256.

Panksepp, Jaak 1998. Affective Neuroscience: The Foundations of Human and Animal Emotions. New York: Oxford University Press.

Pictet, Adolphe 1875[1856]. Du Beau dans La Nature, L'Art et La Poésie. Paris: Sandoz et Fischbacher, Libraires-Éditeurs.

Reber, Rolf 2012. Processing fluency, aesthetic pleasure, and culturally shared taste. In: Shimamura, Arthur P.; Palmer, Stephen E. (eds.), Aesthetic Science: Connecting Minds, Brains, and Experience. New York: Oxford University Press, 223-249.

Ricœur, Paul 2005. The Course of Recognition. (Pellauer, David. trans.) Cambridge, London: Harvard University Press.

Saussure, Ferdinand de 1878. Review article on Adolphe Pictet's Les origins indo-europeennes ou les aryas primitifs, essai de paléontology linguistique (2ème edition). Journal de Genève. April 17.

- 1993. Troisième cours de linguistique générale (1910-1911) d'après les cahiers d'Émile Constantin/Saussure's third course of lectures on general linguistics $(1910-1911)$ from the notebooks of Émile Constantin. [Komatsu, Eisuke ed., Harris, Roy trans.] Oxford: Pergamon.

- 2006. Writings in General Linguistics. [Sanders, Carol; Pires, Matthew, trans., eds.] Oxford: Oxford University Press.

Starr, Gabrielle G. 2013. Feeling Beauty: The Neuroscience of Aesthetic Experience. London, Cambridge: MIT Press.

Thornhill, Randy 2003. Darwinian aesthetics informs traditional aesthetics. In: Voland, Eckart; Grammer, Karl (eds.), Evolutionary Aesthetics. Berlin, Heidelberg: Springer, 9-35.

Ulrich, Roger S. 1993. Biophilia, biophobia, and natural landscapes. In: Kellert, Stephen R.; Wilson, Edward O. (eds.), The Biophilia Hypothesis. Washington; Covelo: Island Press; Shearwater Books, 73-137.

Vartanian, Oshin 2009. Conscious experience of pleasure in art. In: Skov, Martin; Vartanian, Oshin (eds.), Neuroaesthetics. Amityville: Baywood Publishing Company, 261-273.

Velleman, J. David. 2006. Willing the law. In: Cohen, Ronald (ed.), Self to Self: Selected Essays. New York: Cambridge University Press, 284-311.

Vessel, Edward A.; Starr, G. Gabrielle; Rubin, Nava. 2013. Art reaches within: Aesthetic experience, the self and the default mode network. Frontiers in Neuroscience 7(Article 258): $1-9$. 


\section{Двойная сущность наслаждения: желание, воображение и планирование соссюрианского возвышенного и прекрасного в переживании пугающей природы и культуры}

Это исследование стремится обновить и расширить модели мышления и сознания, разработанные Фердинанд де Соссюром для изучения знаков языка. В ответ на его размышления о двойной сущности языка (смесь звуков и понятий) в этом исследовании предлагается теоретизация удовольствия и понимания (смешение разных перспектив), возникающих из нашего взаимодействия с пугающими ситуациями в природе и культуре. Автор начинает с современных нейровизуальных данных, которые показывают, как мы можем извлечь пользу из эмоций малой интенсивности. В то же время доказано, что умственная работа увеличивает интенсивность ощущения удовольствия и восхищения в большей мере, чем инстинкты и предпочтения. Таким образом, в этом контексте соссюрианская сеть различий, по-видимому, способна генерировать мотивированные нейронные связи, которые функционируют для корректировки наших точек зрения. Кроме того, в свете смешения Адольфом Пикте философской эстетики и лингвистики в этом исследовании корректируется неправильное применение другой соссюрианской модели (соединение нашего восприятия времени и пространства, синхронии и диахронии) в понимании кантианских понятий воображения и возвышенного. Подход Пикте позволяет оценить эту модель как проявление строгого и в то же время практического ума, способного разрабатывать множество полезных перспектив. Понятия возвышенного, ужасного и прекрасного уравниваются как законные точки зрения, которые помогают нам справится с угрожающими ситуациями. Наконец, это исследование объединяет и укрепляет соссюрианские модели, сближая их с феноменологическим подходом к нашим воспоминаниям, ощущениям и восприятиям. В заключении автор оценивает эти модели как комбинацию лингвистического, эстетического и морального законов, которые в целом способствуют повышению благополучия сообщества.

\section{Mõnu kahetine olemus: Saussure'liku üleva ja ilusa soovimine, kujutlemine ja kavandamine heidutava looduse ja kultuuriga toimetulekul}

Käesolevas uurimuses püütakse ajakohastada ning laiendada teadvuse mudeleid, mille Ferdinand de Saussure töötas välja keelemärkide hindamiseks. Vastusena tema teooriale keele kahetisest olemusest (helide ja mõistete seguna) pakutakse artiklis välja mõnu ja mõistmise teoretiseerimine (erinevate perspektiivide segamine), mis tuleneb meie suhestumisest looduses ning kultuuris ette tulevate heidutavate olukordadega. Autor alustab kaasaegete ajukuvamistehnikate tulemustest, millest nähtub, kuidas võime saada kasu madala intensiivsusega emotsioonidest. On leitud kasutegureid, mis suurendavad mõnu ja rõõmu, mida me saame pigem sihipärase vaimse tegevuse läbi kui instinktide ja eelistuste kaudu. Seega peetakse saussure'likku erinevuste võrgustikku suutlikuks tekitama motiveeritud neuraalseid sidemeid, mis toimivad meie vaatekohtade kohendajatena. Edasi parandatakse artiklis teise Saussure'i mudeli (meie aja- ja ruumitajude, sünkroonia ja diakroonia ühendamise) vääriti rakendamist 
Kanti kujutlusvõime ja üleva mõistete hindamisel, lähtudes filosoofilise esteetika ja lingvistika segamisest Adolphe Pictet' poolt. Selle asemel, et anda sellele mudelile hinnang kui üheainse ideaalse seisukoha väljendusele, õhutab Pictet' lähenemine meid hindama seda kui range, ent praktilise mõistuse funktsioneerimist, mis suudab välja mõelda arvukaid ja kasulikke perspektiive. Seega võrdsustatakse üleva, ilusa ja inetu mõisted kui legitiimsed seisukohad, millest meil tuleb lähtuda, et tulla toime heidutavate olukordadega kohtumisega looduses ja kultuuris. Lõpuks ühtsustatakse ja tugevdatakse artiklis Saussure'i mudeleid, viies need kooskõlla fenomenolooglise lähenemisega meie mälestustele, aistingutele ja tajudele. Selline lõimimine võimustab meie kujutlusvõimet ja enesekindlust, kui avardame oma vaatepiiri, leiutamaks oma uurimisobjektidele laiemaid kontekste. Kokkuvõttes hindab autor Saussure'i mudeleid kui lingvistiliste, esteetiliste ja kõlbeliste seaduste kombinatsiooni, mis üheskoos teravdavad meie oskust luua lähtealuseid, mis võivad tugevasti kaasa aidata kogukonna heaolule. 